\title{
Participation of High School Students in Authentic Science and Engineering Experiences with a University-Based Water Research Team
}

\author{
Jawaher Alsultan ${ }^{1}$, Michelle Henderson ${ }^{2}$, Allan Feldman ${ }^{1, *}$, Madison Rice ${ }^{3}$, Xia Yang ${ }^{2}$, Jordin Kahler ${ }^{2}$, \\ Sarina J. Ergas ${ }^{2}$ and Kebreab Ghebremichael ${ }^{4}$ \\ 1 Department of Teaching \& Learning, University of South Florida, Tampa, FL 33620, USA; \\ jawaheralsul@usf.edu \\ 2 Department of Civil \& Environmental Engineering, University of South Florida, Tampa, FL 33620, USA; \\ mbhenderson@usf.edu (M.H.); xiayang@usf.edu (X.Y.); jordinkahler@usf.edu (J.K.); sergas@usf.edu (S.J.E.) \\ 3 Kimley-Horn and Associates Inc., Raleigh, NC 27601, USA; madisonleighrice@gmail.com \\ 4 Patel College of Global Sustainability, University of South Florida, Tampa, FL 33620, USA; kebreab@usf.edu \\ * Correspondence: afeldman@usf.edu; Tel.: +1-813-974-2471
}

\section{check for} updates

Citation: Alsultan, J.; Henderson, M.; Feldman, A.; Rice, M.; Yang, X.;

Kahler, J.; Ergas, S.J.; Ghebremichael,

K. Participation of High School

Students in Authentic Science and

Engineering Experiences with a

University-Based Water Research

Team. Water 2021, 13, 1745.

https://doi.org/10.3390/

w13131745

Academic Editor: Athanasios Loukas

Received: 11 August 2020

Accepted: 21 June 2021

Published: 24 June 2021

Publisher's Note: MDPI stays neutral with regard to jurisdictional claims in published maps and institutional affiliations.

Copyright: (C) 2021 by the authors. Licensee MDPI, Basel, Switzerland. This article is an open access article distributed under the terms and conditions of the Creative Commons Attribution (CC BY) license (https:/ / creativecommons.org/licenses/by/ $4.0 /)$.

\begin{abstract}
The lack of readily available sources of potable water is major problem in many parts of the world. This project engaged high school (HS) students in authentic and meaningful science and engineering activities to teach them about the lack and poor quality of potable water in many regions and how they can be addressed through the use of point of use (POU) treatments, such as biosand filters (BSFs). The HS students' activities paralleled those of USF students, including research question development and BSF design, construction, operation, and monitoring. An ethnographic approach was utilized by incorporating participant observation, collection and review of artifacts, and interviews. It was found that the project's focus on the need to provide potable water in the developing world provided authenticity and meaningfulness to the HS students, which encouraged their participation in activities and the learning of science and engineering practices. The HS students reported an awareness of the differences between this project and their regular science classes. The project had a positive impact on their perceptions of themselves as scientists and their interest in STEM careers. The HS students' results were useful to the university-based research. In addition, the USF students gained teaching experience while investigating research questions in a low-stakes environment.
\end{abstract}

Keywords: science research; engineering research; science education; science and engineering practices; biosand filters

\section{Introduction}

Middle and high school science curricula in the United States (US) and elsewhere often include topics related to the availability and quality of water for human use. In addition, numerous projects have been funded to develop new curricular materials and for the study of a variety of methods to engage students in learning about water issues [1-3]. A challenge to educating young people about water issues is that much of school science has been described as abstract, difficult to learn, and unrelated to application in daily lives [4-8]. For example, when water-related subjects are integrated into the science curricula, learners are often detached from the real environment due to the lack of field experiences, limited or no connection with real-world problems, and lack of incorporation of science and engineering practice into school activities [9-15].

In our study we engaged HS students in authentic science and engineering activities that permitted them to learn scientific principles while participating in research in a manner that was similar to how scientists and engineers conduct research [16-18]. When students engage in practice-based authentic scientific research and engineering research, 
they construct research questions, plan studies, make observations, and draw conclusions based on evidence and interpret research reports [19].

A growing body of evidence has shown that engaging students in authentic science and engineering experiences has a variety of positive outcomes; this includes enhancing their motivation for STEM disciplines, increasing the understanding of science content, improving confidence and self-esteem in the ability to become scientists, and developing critical thinking skills [20-24]. In environmental education, the engagement of students in authentic science has been performed through citizen science approaches $[25,26]$, summer internships [27-29], afterschool programs [30], and classroom-based experiences [31-33]. Our project is most similar to the approach used by Chapman and Feldman [31], in which students and their teacher were mentored by a university faculty member and doctoral student in performing research on algae growth for biofuel production. The approach used in the current study builds on their work by rendering the partnership between the university and school more collaborative in nature. We discuss this in more detail below.

In this paper, we report on our study where we engaged high school (HS) students in authentic and meaningful science and engineering activities in order to teach them about the lack and poor quality of potable water in many regions and how they can be addressed through the use of point of use (POU) treatments, such as biosand filters (BSFs). In doing so, we provided the HS students with the opportunity to learn practices used in science and engineering [19]. A novel aspect of our study was that the HS students and their teacher engaged in these activities in collaboration with engineering research being performed at the University of South Florida (USF). An important aspect of this was that the university and HS projects overlapped, with each group learning from the experiences of the other group.

For this paper, our overarching educational research question was, "How does involvement in a science and engineering project that focuses on providing potable water in developing countries, in collaboration with a local university, affect HS students?" We looked at this research focus with the following sub-questions:

- How did the BSF project's focus on the need to provide potable water in the developing world affect its authenticity and meaningfulness to the HS students?

- How did the authenticity and meaningfulness of the HS activities affect the students' learning of science and engineering practices?

- How did their participation affect their attitude toward science, including participating in science, their interest in science-related careers, and their identities as scientists?

\section{Background}

In this section we lay out our theoretical framework, which combines the ideas of authenticity and meaningfulness of science activities and water literacy with learning how to conduct science. The final section provides some background on the focus of the university-based research on the use of BSFs as a POU water treatment. We begin with a look at what we mean by authentic science.

\subsection{Authentic and Meaningful Science in Schools}

One of our goals in this project was to engage the HS students in authentic and meaningful science and engineering activities. Brown, Collins, and Duguid [34] describe authentic activities as the "ordinary practices of the culture" by which "meanings and purposes are socially constructed through negotiations among present and past members" (p. 34). Similarly, Braund and Reiss [35] argued "authentic school science should provide experiences that are more in line with the sorts of activities that scientists and technologists do in the real world of science and that such experiences should include student-directed tasks and more open-ended enquiries" (1375-1376). In the US, the science education community has adopted the language of science and engineering practices to describe what it is that scientists and engineers undertake. A Framework for K-12 Science Education [19] argues that students should not only learn the content of science but also the practices of science and 
engineering. These practices include asking questions and defining problems; developing and using models; planning and carrying out investigations; analyzing and interpreting data; using mathematics and computational thinking; constructing explanations and designing solutions; engaging in argument from evidence; and obtaining, evaluating, and communicating information. Although school science activities often mimic these practices, they differ cognitively and epistemologically from science conducted by scientists [36,37]. Given our goal to engage HS students in an actual scientific research study, we expected that they would experience science that is "authentic" rather than "school science".

Recently Burgin [38] developed a three dimensional model of authentic inquirybased science practices. He argues that scientific inquiry primarily requires only four of the eight practices included in the framework. They include the following: asking of questions; planning and carrying out of investigations; analyzing and interpreting data; and communicating information. Our project also engaged students in the problem setting and design processes that the framework [19] associates with engineering rather than science. Although school science activities often include Burgin's four practices in some manner, performing them does not make the experience authentic to students, as we noted above. Burgin continues by arguing that what makes it authentic or not depends upon (i) how meaningful or significant the investigation is to the student; (ii) the significance of the work to others, such as members of the scientific community; and (iii) how much the students' activities resemble the practices as engaged in by the community of scientists.

The meaningfulness of the engagement in scientific practices was also explored by Berland et al. [37]. While the main focus of their article was students' development and the use of epistemic ideas in science, we found their continuum of methods that classroom communities engage in scientific practices useful for our understanding of the meaningfulness and authenticity of the BSF project for the HS students. On one end of the continuum are activities that are meaningful to the classroom-what we refer to in this paper as school science. On the other end are activities that are meaningful to the scientific community. The meaningfulness of each is dependent on how much the activities align with the epistemic goals and knowledge building approaches used in the two types of communities. If the focus is too much on school science, then the students do not gain an understanding of how science makes sense of the world; and if the focus is too much on scientific approaches, then the students might engage in the practices without understanding why they are doing so or for what purpose. Meaningful engagement in scientific practices in the classroom lies somewhere between the two ends of the continuum (see Figure 1).

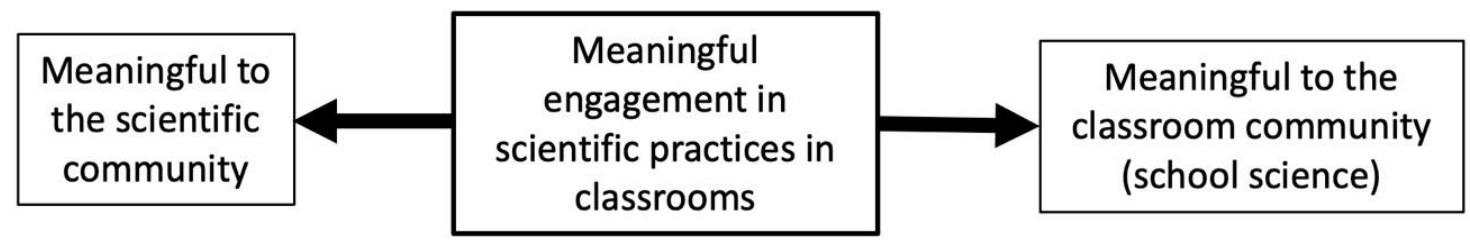

Figure 1. The continuum from Berland et al.: Meaningfulness of the Engagement in Scientific Practices [figure based on Berland et al. (2016)].

\subsection{Research on Water Education in K-12 Schools}

In this study the global need for safe accessible water was conceived as a method to render the HS students' engagement in research on the design and use of BSFs meaningful to them. We also wanted them to become aware of the issues surrounding the scarcity of potable water in many regions of the world. The latter could fall under the rubric of "water literacy", which includes hydrosocial knowledge related to water scarcity and human health and welfare; local knowledge related to the water sources available in the developing world; and functional knowledge about water systems [3]. Carroll and Hamann suggested three areas of focus for the improvement of water literacy. First, they suggest a focus on removing or alleviating misconceptions and misunderstanding about water. 
Second, they call for an emphasis on place-based learning to increase local knowledge and to connect better with the behavioral and affective domains. Finally, they note the need for both hydrosocial and functional knowledge because, "the future of water management and water justice needs citizens and leaders who firmly understand the numerous and complicated connections between water resources, human activities, and culture" [3].

A review of the prior literature showed that most studies used traditional materials or methods $[9,14]$ and spanned all grade levels from preschool to HS. For the most part they found that students gained knowledge and understanding about water issues and improved their attitudes toward water conservation. However, it was also reported that the gain in knowledge and understanding did not necessarily result in the adoption of pro-environmental behaviors. This lack of connection between knowledge and action has been frequently documented in the literature (see, for example [39]).

The remainder of the intervention studies used materials and/or methods that were innovative. Innovative examples include those described as inquiry-oriented, e.g., [10,40]; a science, technology, and society approach implemented [41]; the use of cartoons to raise awareness of water issues among grade 4 children [42]; and a study by Davis and Schaeffer [43] to critically engage Black children in socio-scientific explorations of water and water access in relation to the water crisis in Flint, MI in the US. In general, these more innovative interventions resulted in the students gaining a sense of agency to affect changes in their own, their family's, and their community's behaviors.

We performed a search and review of the literature using ERIC and Google Scholar for intervention studies that attempted to address the shortcomings in students' water knowledge. We searched for those that incorporated water related material into existing science and/or social studies curricula. Most of the intervention studies we found used somewhat traditional materials or methods. These included studies performed in Australia [44], China [15], Jordan [13], Morocco [9], Thailand [45], Canada [14], and the US [46] and spanned all grade levels from preschool to HS. For the most part, they found that students gained knowledge and understanding about water issues and improved their attitudes toward water conservation. However, it was also reported that the gain in knowledge and understanding did not necessarily result in the adoption of pro-environmental behaviors $[47,48]$. This lack of connection between knowledge and action has been frequently documented in the literature (see, for example, Kollmuss and Agyeman [39]).

The remainder of the intervention studies used materials and/or methods that were innovative. Examples include those described as inquiry-oriented, e.g., Condon and Wichowsky [10] and Halsey Randall [49] conducted in the US and Coban et al. [40] in Turkey; a science, technology, and society (STS) approach implemented in Finland by Havu-Nuutinen et al. [41]; the use of cartoons in Oman to raise awareness of water issues among grade 4 children [42]; and a study by Davis and Schaeffer [43] to critically engage Black children in socio-scientific explorations of water and water access in relation to the water crisis in Flint, MI, in the US. In general, these more innovative interventions resulted in the students gaining a sense of agency to affect changes in their own, their family's, and their community's behaviors.

One of the things that these studies had in common was that, to a large extent, they were place-based [50,51]. That is, they were concerned with water issues local to the schools. This is different from our study, in which the BSF activities were connected to potable water issues that were geographically far removed from the students in sub-Saharan Africa. However, as we show below, some of the students did have experience with issues related to potable water. Our study also differed from those reported above in that the HS students engaged in science and engineering activities that were closely related to research being performed by the research group at USF.

\subsection{Learning to Do Science}

For students to engage in authentic science and engineering practices, they must gain the knowledge and skills needed to engage in the practices. In order to understand how 
this happens we use a model of how students learn to conduct science by participating in research groups $[52,53]$. This model was developed by examining the methods in which undergraduate and graduate students learn how to conduct research when they were engaged in a study on the natural remediation of acid mine drainage $[54,55]$. When students participated in research groups, they participated as apprentices $[52,53,56-58]$. As apprentices, the students are legitimate participants in the research groups [59] and learn by action, by interacting with peers and mentors, and by using the tools required for research in their field. As students engage in authentic and legitimate practices over time, they develop the methodological and intellectual proficiency needed to become knowledge producers [52]. As Lave and Wenger (1991) demonstrated, as the proficiencies of apprentices - the students-grow, their participation became less peripheral and more integral to the functioning of the group and therefore more authentic to the practices of scientists.

Implementing this model in high schools is different from implementing the model at universities. First, if the experience for the HS students is built into a regular course in which they are enrolled, as is our project, they do not have the opportunity to be immersed in the work of a research group as university students are immersed. Therefore, while the HS students experience could be categorized as authentic, it would not have the immersion in active research groups that results in the legitimate peripheral participation as apprentices that the university students experience. Secondly, in university-based research, the students who have the opportunity to participate in research groups are typically highly motivated to do so [60]. At the HS level, the students often need to be convinced that performing the extra work required to participate authentically in science activities is worth performing. According to Burgin [38], this would require the research project to be meaningful to the students, to use practices similar to those used by scientists, and to produce results that are significant to others. One method to make this happen is by creating partnerships between schools and universities through real-world problems (e.g., lack of potable water), the engagement of the students in science and engineering practices [19], and with the student-developed products (i.e., the results of their investigations) being beneficial beyond the school walls, and in our case, to the university-based research group, which has its goal to improve the water treatment technology that could be used by many communities around the world. As a result, the students' learning would be authentic since they engage in educational activities they find relevant and meaningful $[37,38,61,62]$.

\subsection{The Need for Point of Use Water Treatment}

The university-based research program in our project focused on the problem of providing safe, efficient, and low-cost POU water treatment. The lack of potable water is a significant global challenge. More than 800 million people worldwide lack basic drinking water services [63] and UNICEF [64] reported that in 2017, 435 million people used unimproved drinking water sources, such as unprotected wells or springs. In addition, 144 million people collected drinking water from rivers, lakes, or other surface waters that may be unsafe. Consumption of contaminated drinking water can cause waterborne diseases, such as Hepatitis A, Giardiasis, and Cholera. Unsafe drinking water services disproportionately affect people living in developing countries. Each year, nearly 300,000 children under the age of five die due to diarrheal diseases, which are preventable through proper water and sanitation infrastructure and education. In working with the HS students, we began by providing them with an overview of this worldwide hydrosocial problem (see Table 1). As we show later in this paper, this issue was sufficient for rendering the research meaningful to the HS students.

In regions where a centralized water treatment is not available, POU water treatmenti.e., treatment at the location where water is consumed, such as at home or school-is a viable option. The POU treatment being studied at the University are BSFs, which are widely used in developing countries. BSFs are typically a concrete or plastic container with sand and gravel media (CAWST, Calgary, AB T2H 2L8, Canada, 2012). An important 
aspect of BSFs is the elevated outlet pipe that maintains about $5 \mathrm{~cm}$ of water above the sand surface and keeps the sand saturated. The moist condition promotes the growth of a beneficial biolayer at the top part of the sand bed called the "schmutzdecke". As the biolayer grows, it improves the quality of the treated water by trapping particles (measured as turbidity), pathogens (measured as fecal indicator bacteria (FIB)), and organic matter (measured as UV254 absorbance) $[65,66]$. Organic matter is biodegraded by microbes, particles are removed by being trapped in the pore spaces and attached to the filter media, and pathogens are removed through adsorption, predation, competition and natural die-off in the schmutzdecke and the sand bed below it [67]. BSFs must also be properly operated and maintained and, therefore, users require functional knowledge for them to work effectively [68].

Table 1. Scaffolding activities and their relationships with science and engineering practices.

\begin{tabular}{c}
\hline Focus of Activity \\
Background Knowledge \\
of Water Issues and BSFs \\
Defining Problems and \\
Designing Solutions
\end{tabular}

Asking Questions

Planning and Carrying Out Investigations

\author{
Analyzing and \\ Interpreting Data
}

\section{Communicating Information}

\begin{tabular}{|c|c|}
\hline Scaffolding Activities & Data Collected \\
\hline $\begin{array}{l}\text { Introduction to the worldwide } \\
\text { problem of lack of potable water and } \\
\text { how BSFs can be used to address } \\
\text { this problem. }\end{array}$ & $\begin{array}{l}\text { Student interviews and } \\
\text { classroom observations. }\end{array}$ \\
\hline $\begin{array}{l}\text { Students engaged in creating an } \\
\text { affordable and user-friendly design of } \\
\text { BSF that maximizes performance and } \\
\text { removes multiple contaminants. } \\
\text { USF team and Mr. Munro reviewed } \\
\text { the students' desions. }\end{array}$ & $\begin{array}{l}\text { Students' sketches of their } \\
\text { BSF design and their final } \\
\text { reports, interviews, and } \\
\text { classroom observations. }\end{array}$ \\
\hline
\end{tabular}

Students constructed the BSFs.

Presentation that guided students through the question generation process.

Students engaging in the whiteboards activity to develop research questions USF team and Mr. Munro's reviewed review of students' questions.

Students designed their experiments based on their research questions. Students collected data for their experiments.

Students analyzed their data and compared the results against the control.

Students wrote their final reports to answer their research questions.

Students presented and shared their designs and final reports with others.
Whiteboards and classroom observations.

Students' BSF data and final reports and classroom observations.
Students' BSF data and final reports and classroom observations.

Students' sketches, final reports, and interviews.

Building of Expertise

Learning of Science and systems, hydrosocial, local, and functional knowledge of water issues.

Students were able to translate their understanding of the BSF mechanisms to design and build the two-bucket design for their experiments.

Students' knowledge of concepts and practices of BSFs was reinforced.

With the support of the USF team and Mr. Munro, they were able to identify key variables that can impact BSF performance.

Students combined theoretical concepts and physical models

to test their hypotheses.

Students were able to collect evidence and explain the results and make conclusions based on data.

Ability to explain to others what was conducted in the project and why.

Although BSFs are effective at removing pathogens that cause many waterborne diseases, their ability to remove harmful inorganic compounds, such as nitrate, arsenic, and fluoride, is limited [69]. Where water sources contain both pathogens and dissolved inorganic contaminants, conventional BSFs require modification in order to effectively produce safe drinking water.

In this section we describe the project that we implemented at a local HS, give a brief overview of the water research project concurrently performed at USF with the HS project, and the methods used for the educational research. 


\section{Context and Participants}

This study took place at a southeastern US high school in which $83 \%$ of the students qualified for free or reduced lunch. The school was recommended to the USF team by the district's director of STEM education based on two factors: first, the school was part of a STEM education innovation hub; and second, Mr. Munro (pseudonym) was recognized as a highly skilled teacher open to innovating in his classroom. Mr. Munro taught six sections of a science elective each day, with a total of approximately 110 grade 11 and 12 students. All of his classes participated in the project. The University's Institutional Review Board (IRB) and the school district's office approved this study. All participants provided their consent to participate. We used pseudonyms throughout this paper for the teacher and HS students. The USF team consisted of three faculty members: one Science Education professor (Feldman), one Global Sustainability professor (Ghebremichael), and one Environmental Engineering professor (Ergas). The graduate student team consisted of one education doctoral student (Alsultan), three environmental engineering graduate students (Henderson, Rice, and Yang), and one environmental engineering undergraduate student (Kahler).

\subsection{School-Based Activities}

The design of the school-based activities was based on results from Feldman's program of study on how people learn to perform research $[31,52,53,70,71]$. He developed a model of collaboration between university researchers, school teachers and students engaging in parallel research projects. In this model of collaboration, the teachers and students engage in research activities that extend the university faculty member's research group into the school setting. In the project reported here, we used this collaborative approach to engage both HS students and university students in water and sanitation engineering research. The university students engaged in research on the development of a two-stage BSF design that can remove both particulate and dissolved contaminants. The HS students engaged in authentic science and engineering activities that paralleled those of the university students. In this manner, the HS students' participation was similar but not the same as university students in their research groups. Therefore, while the HS students' engaged in science and engineering activities, they did not have the university students' rigorous experience as apprentices in legitimate peripheral participation.

The science and engineering activities were structured so that the students were engaged in the practices of science and engineering [19]. Since Mr. Munro was not familiar with the use of BSFs or the research methods that were being used to study the BSFs, much of the instruction of the students was performed by the university team. During initial visits, students were introduced to issues related to global water supply and quality, the project goals, and their roles in the project. The university team developed an introductory PowerPoint that provided background information about issues related to lack of potable water, waterborne diseases, and methods to purify water; and a booklet about the construction and use of BSFs. Later on, the university team visits focused on building the BSFs, the development of research questions, study design, data collection and analysis, and report writing (note: all materials developed for this intervention are available on the project website: [https:/ / www.usf.edu/nsf-ires/research/supplementarymaterials-for-maccan-project.aspx] (accessed on 11 August 2020). The activities and their relationship with the science and engineering practices are summarized in Table 1 . The university team regularly reminded the HS students that they were engaging in research activities similar to those conducted at the university and that the results from the HS students' research could be useful for university-based research. They were also reminded that their work could potentially help people who lack a ready source of potable water.

Concurrently with the school-based activities, two environmental engineering graduate students (Rice and Yang) engaged in research on BSF's under the direction of Ergas and Ghebremichael. Their methods and results are reported in Rice's thesis [72]. 
Their research goals were to design a two-stage BSF from low cost and locally available materials; compare the performance of the two-stage BSF with a conventional BSF system; and to investigate the potential to use the two-stage BSF design to remove sediments, pathogens, and dissolved inorganic contaminants. We describe the manner in which the school-based and university-based activities related to one another below.

\subsection{Data Collection and Analysis}

To answer the educational research questions, we used an ethnographic approach [73,74] in which USF team members were participant observers. We also collected a variety of data including exit interviews of a subset of the HS students, observations of their engagement in science and engineering practices, and artifacts they produced.

Observations of the students' engagement in the project were made two to three times per week during Spring 2019. Observations occurred when the University team members visited the school to help the students engage in activities. The observations provided an in-depth look at the classroom learning environment, which allowed for a detailed understanding of students' experiences during the project, including the level of student engagement and performance; their implementation of science and engineering practices; and their interactions with the university team, their peers, and Mr. Munro. Sketches of student BSF designs and explanations; photos of student whiteboards used for the development of their research questions; BSF data collected by students; and student final reports were also analyzed (note that an example of a student sketch and student whiteboard are provided later in the article).

Exit interviews were performed with HS students at the end of their involvement in the project. The interview questions were designed to uncover the HS students' beliefs about the goals of the project and its importance; their perceptions of what science is and who scientists are; the similarity and differences between this project and their regular school science classes; their attitudes toward science, including their capacity to undertake scientific research; and their interest in STEM careers. The interview also asked about their feelings toward being part of a group that working to enhance the daily life of communities in developing countries that lack potable water; and how it affected their perceptions of the importance of clean water in those countries. In addition, we asked whether they had made changes in their daily use of water. We concluded the interview by asking what the most important things they learned from the project is and if they had anything else to add. The questions also asked about their knowledge of water supply and quality issues. Fifteen student volunteers were interviewed. They were from the six class sections and varied by gender, ethnicity, and grade level (11th or 12th).

We recorded the student interviews, transcribed and coded them using preconceived categories derived from the literature on water education, science education, and learning to perform science, as well as science and engineering practices as described in the framework [19]. Emergent categories were derived inductively from the data by using the methods for the development of the grounded theory [75]. We began with open coding to identify themes and patterns and then we used axial coding to group and label the themes and patterns into categories and concepts [76]. They then conferred with one another to compare, contrast, and to come to a consensus about the use of the categories. This process was performed by several members of the USF team who were trained in qualitative research methods. It is important for us to make clear that the team members who conducted the analysis were also instrumental in implementing the project in the school. Therefore, they may have had an implicit bias toward looking for evidence that demonstrated the success of the project. Multiple reviews of the data and the findings by multiple team members helped to soften any bias effects.

We analyzed the student artifacts by reading and reviewing them as they were collected and through writing analytic memos. In addition, we developed a rubric to analyze the illustrations and descriptions in the students' BSF designs. For the illustrations, we looked at clarity, details, and included components; and for the descriptions we looked 
for clarity, details, quality of explanation, and creativity of their designs. We coded their final reports in a similar manner to how we coded the interviews. We began with the same codes we used for the interviews and allowed for emergent categories. Observations were discussed at weekly meetings of the USF team and through writing analytic memos. After analyzing all our data, we triangulated our results using the interviews, artifact review, and observations.

\section{Results}

The purpose of this study was to examine how involvement in an authentic science and engineering project in collaboration with a local university that focuses on research for providing potable water in developing countries affects HS students. In this section we report on our findings for each of our sub-questions.

\subsection{How Did the BSF Project's Focus on the Need to Provide Potable Water in the Developing} World Affect Its Authenticity and Meaningfulness to the HS Students?

Over the course of the semester, we introduced the HS students to issues such as access to clean water for people in developing countries and how BSFs can help address them. We then challenged the HS students to design a method to use two standard five-gallon plastic buckets as the body of a BSF and instructed them on how to develop researchable questions and the methods needed to measure the quality and quantity of water that passes through the BSFs. They then proceeded to run the BSFs by charging them daily and collected data for six weeks on a weekly basis. At the end of that time period, they analyzed their data and presented their results in a report. These correspond to the practices Burgin [38] identified as being necessary for school-based inquiry to be authentic.

An important part of this project was its focus on the real-world problem of providing a low-cost means for people in the developing world to have a POU method for producing potable water. This focus provided the HS students the opportunity to learn hydrosocial knowledge related to water scarcity and human health and welfare; local knowledge related to the water sources available in the developing world; and functional knowledge of how BSFs can be used to make water potable [3]. During our first visits to the science classes, we presented the information to the HS students in two formats. One was a PowerPoint presentation about water sources, water scarcity, water quality issues, water treatment in our region, POU water treatment, and BSFs. The PowerPoint included a brief video "Water Walk" that showed a young girl in Africa walking four miles each way to fetch water from a muddy stream [77]. The other format was a booklet produced by a USF student (Alsultan) that included information about BSFs and how they treat water; and about water supply issues including the health effects of contaminated water.

In our interviews with the HS students, we asked them what the purpose of the BSF project was, whether they felt it was important, and how they felt about being part of a project working to enhance the daily lives of people in developing countries. They responded in a manner that indicated being a part of a project with real-world implications led them to feel mature, responsible, and felt that they were able to create changes in the world. For example, Alejandro stated the following:

There was a level of maturity, um, some kind of level of discipline when it came to this project specifically just because we're actually doing something serious here. We're working on something that could change the lives of potentially millions of people...

He further emphasized how participating in this project increased his awareness of the quality of life and social justice:

We're living here in America and we have water, we have food, we have electricity, we have pretty much any kind of commodity that people in other countries don't have. I think it's, it's a huge disadvantage, um, for anyone else. And really, we should try to support anyone else who doesn't have commodities. And specifically, for this project, we're really trying to get them to have clean water, which is why we're making these biosand filters samples here. 
Carla told us of how cooperating with scientists to solve a real-world problem helped in developing her higher thinking skills:

We could help USF find a way to get people who all around the world who don't have water like purified water, get purified water... And it actually helped me to like, think more and go like outside the box because you had to think about daily things you use in order to create the biosand filter, which is really nice.

In a final example, Luna told us:

Well when you guys came, you showed us a video of this little girl going uphill and like we as Americans, we don't think of what people have to go through and other countries to struggle to go get water. A little girl going up a hill so far just to get a drop of dirty. Who knows what's in that water to get some water supply that hurts? So us doing the biosand filter we like, we feel like we're helping ... I feel special ... I feel more empowered! Oh, I'm doing something good for people in Africa and all those countries that don't have like third world countries that don't have the water supplies that we have here".

These students' statements and those of others emphasized the importance they saw of working in a real world problem, how their participation heightened their social awareness, and their global civic responsibility [78]. In addition, according to Burgin [38], authenticity is increased when the results of the scientific activities are significant to others. In addition, we observe how the structure of the school-based project being similar to and overlapping with the university-based project helps to place the former on Berland et al.'s [37] continuum as a meaningful engagement in the scientific practices in the classroom.

\subsection{How Did the Authenticity and Meaningfulness of the HS Activities Affect the Students' Learning of Science and Engineering Practices?}

We now look at the manner in which HS students engaged in science and engineering activities as part of the BSF project. This section is arranged by the science and engineering practices in which the HS students engaged in [19].

\subsubsection{Defining Problems and Designing Solutions}

We structured the project so that the HS students would progress through a series of guided activities related to the research being conducted at the university (see Table 1). After providing the HS students with background information on BSF's and their use, we challenged them to come up with a design for a two-stage BSF that they would compare with a conventional single-stage BSF manufactured by Hydraid, Inc. According to the framework [19], this design problem fits under the heading of engineering rather than science. The framework notes that defining problems occurs in consultation with "clients". The USF team acted as the clients for the HS students because they were told that the design that they would come up with would make use of the university-based research project. Before starting the designing, they were provided with information about the parts of a BSF and were shown one Hydraid BSF. A design competition was held among Mr. Munro's six classes to develop an alternative design to the Hydraid BSF. The goal was to create a more affordable and user-friendly design that maximizes performance and the ability to remove multiple contaminants. The HS students worked in small groups or individually to come up with their possible solutions to the problem. The students laid out their solutions in diagrams and associated descriptions. Most of the designs focused on the requirement to somehow stack the two buckets in a manner that allows water to flow from the top bucket to the bottom one without leakage. Others provided more detail including diffusers and media (see Figure 2). Notably missing was the requirement for the outlet tube to be placed above the biolayer. The USF team reviewed all the designs and provided the students with feedback, which was used to finalize the design. 


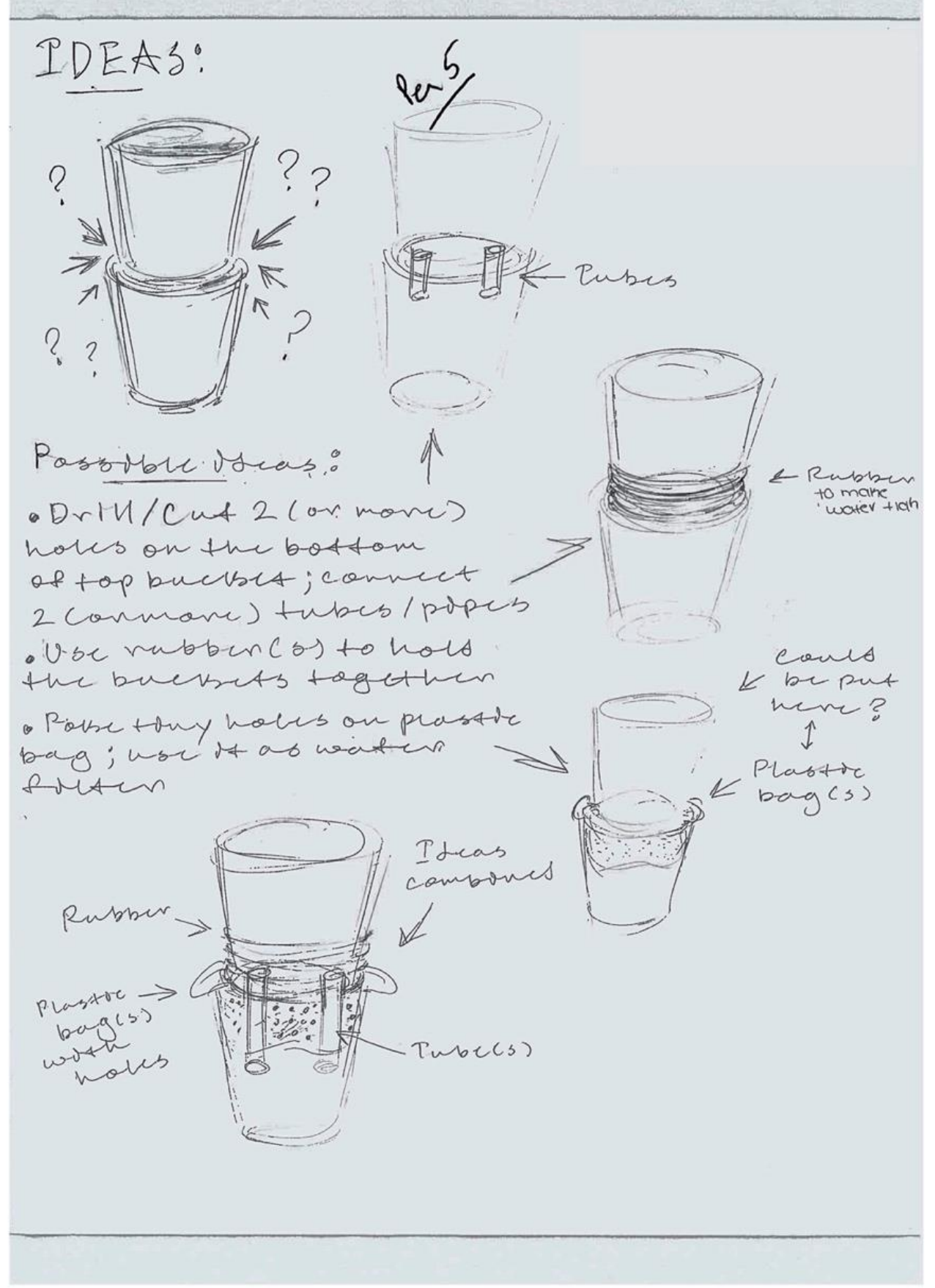

Figure 2. Sample student design for two-bucket BSFs.

The resulting design met the required specifications for a BSF and were constructed by the HS students from two five-gallon plastic buckets (Figure 3). They used hand and power tools to construct the two-bucket BSFs and leak-tested their design to determine if new seals and caulking were needed. Therefore, with guidance from the USF team and Mr. Munro, the HS students collaboratively designed and constructed a solution to the problem of constructing two-stage BSFs from five-gallon buckets.

As we noted above, the graduate students (Rice and Yang) worked with the HS students on all aspects of the school-based project during the same period of time where they were conducting their university-based research. Rice and Yang's first objective was similar to the HS students' design problem: to design a two-stage BSF from low cost and locally available materials. They began their design process with the HS students' 
successful two-bucket design. Since Rice and Yang needed to have access to the media in at least one of the buckets, they modified the HS students' design as shown in Figure 4A,B.

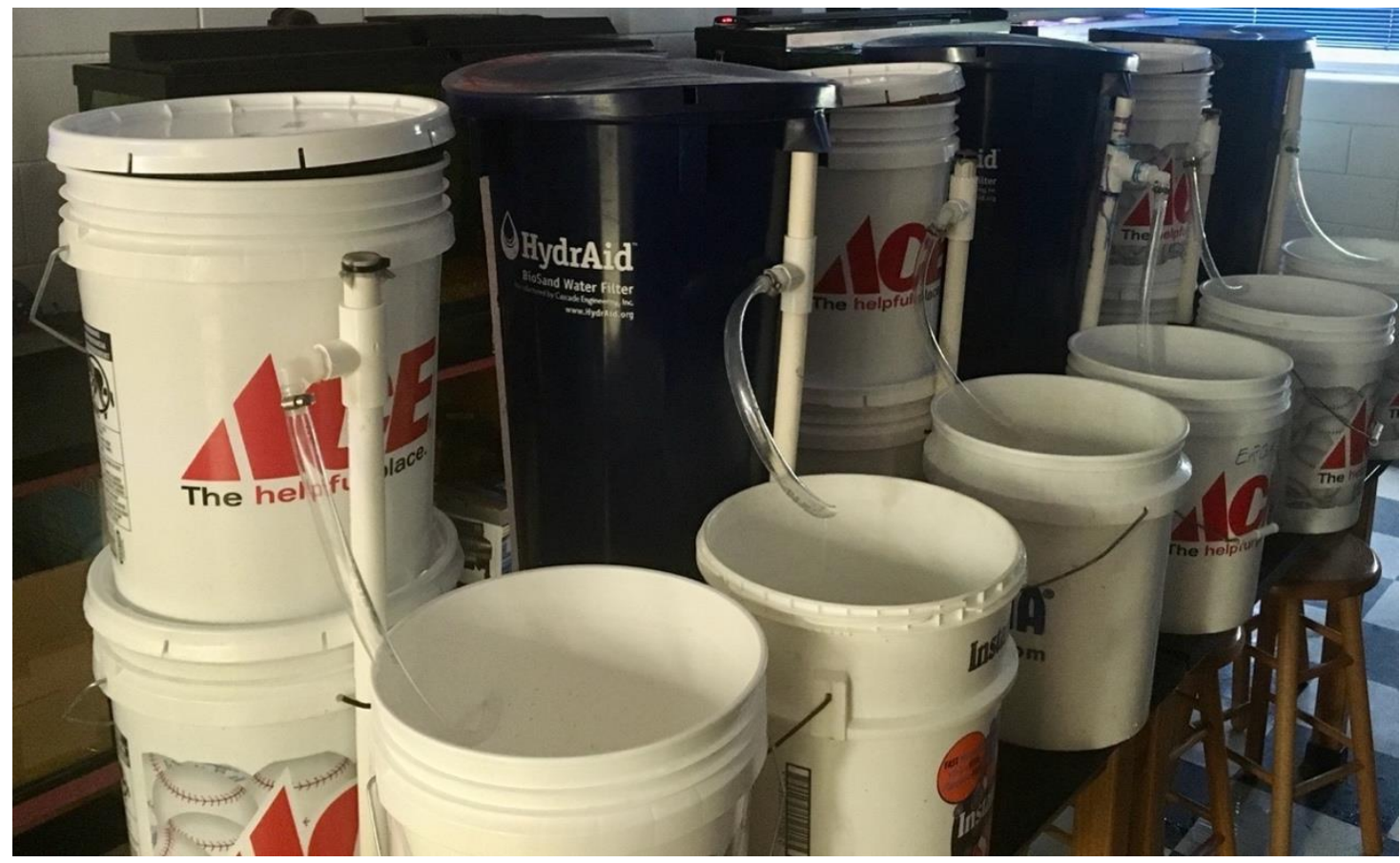

Figure 3. Two bucket BSFS and HydrAID commercial BSFs in the high school laboratory.

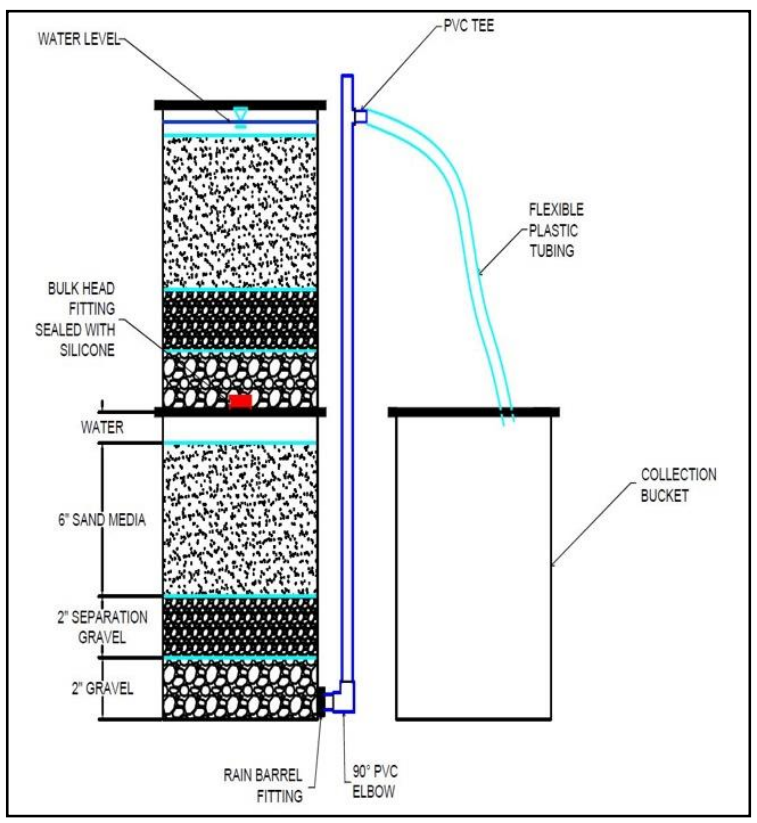

(A)

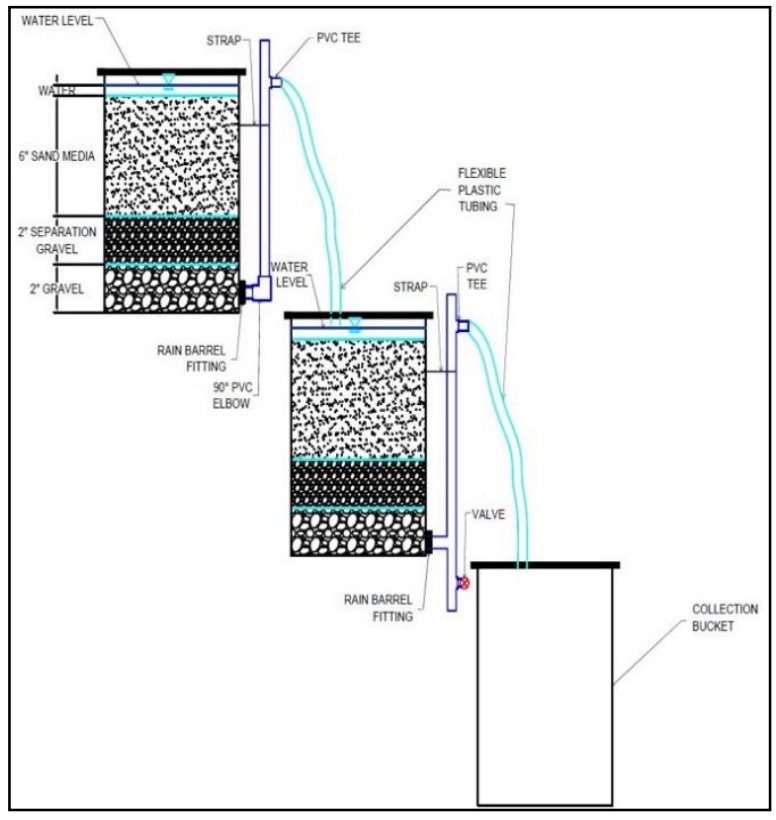

(B)

Figure 4. (A) Schematic diagram of the two-stage BSF design developed by the HS students. (B) Schematic diagram of the two-stage BSF design developed by the Rice and Yang.

Both Burgin's [38] framework and Berland et al.'s [37] continuum are specificifically for science rather than engineering as they are described in the framework [19]. However, the collaboration between the USF team and the HS students for the design and construction of the BSFs required their respective research added to the authenticity of the HS students' design process. In addition, their resulting design was significant to others-Rice and 
Yang-because they used the HS students' BSF as a basis for the university design. The HS students were made aware of this by the formal presentations of the USF team as well as through informal conversations between the two groups. In addition, the design process used by the HS students could be seen as an example of engagement in engineering practices in the classroom, which increased its meaningfulness to them [37].

\subsubsection{Asking Questions}

The HS students were then guided in the development of their research questions, which corresponds to the practice Asking Questions. This was performed by providing them with the structure of a question "How does $A$ affect $B$ of $C$ ", where $A$ is the independent variable, $B$ is the dependent variable, and $C$ is the subject of the experiment. They were also provided with possible independent variables: cleaning frequency, charge volume, pause periods, design of the BSF (Hydraid or two-stage), and substrate (corn syrup) addition; and possible dependent variables including flow rate, turbidity, $\mathrm{pH}$, nitrate, nitrite, and ammonia concentrations (see Figure 5 for an example of the whiteboards).

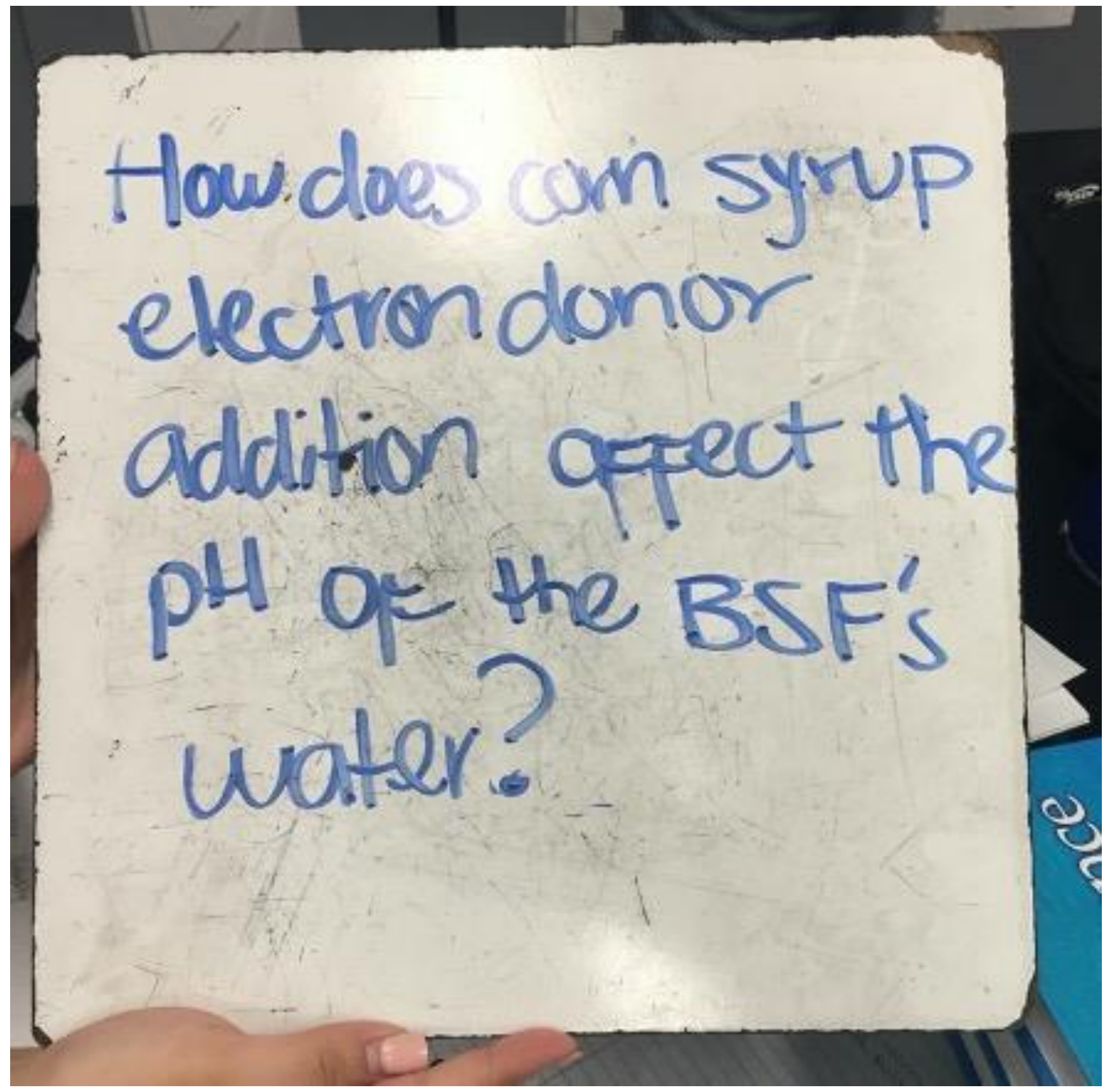

Figure 5. Student generated research question displayed on a whiteboard.

The student generated questions were reviewed by the USF team and Mr. Munro. They found the following to have both the correct relationships between the independent 
and dependent variables and the subject of the experiment. Furthermore, both sets of variables were measurable using the materials available in the school or on loan from USF:

- How does the cleaning frequency of the BSF affect the quality of the filtered water?

- How does the charging volume affect the quality of the filtered water?

- How does the type of BSF affect the quality of the filtered water?

- How does the addition of corn syrup affect the quality of the filtered water?

- What are the best methods to operate the BSF to produce the highest quality of water with the least amount of maintenance?

The HS students' research questions were similar to Rice and Yang's. Their overall research questions were the same: whether it is possible to design a low cost two-stage BSF to produce high quality drinking water. More specifically, both groups compared the performance of the BSFs to commercial designs and investigated the potential of their designs to remove particulate and dissolved matter. That said, the HS students were looking at dissolved nitrate and nitrite, while the USF students were investigating fluoride removal.

These similarities can be observed in the HS students' response to our interview question about the purpose of their research. Some examples include Marco, "[The goal of the research was] finding out how effective the biosand filter is in filtered water, taking out the nitrates and how effectively it cleans dirty water"; Manny, "The purpose of doing this is [was to see] how it works and see the consequences of pros and cons of it and how to improve it"; and Alberto, "I think the goal is to find a better way to clean the water". We found similar responses in the final reports. As in the interviews, the HS students referred to the need for potable water. In addition, they included the specific research questions that guided their groups' part of the overall project.

The students' responses could be observed as the result of their engagement in the practice of Asking Questions in a manner that promotes the rote learning of skills. For it to go beyond that, Berland et al. (2016) argue that practices of science need to be both meaningful to the classroom community and meaningful to the scientific community. We see evidence of the responses in which they noted their work was meaningful to them because the project had real-world implications for people in other countries and, for some, their experience with their families in their home countries. Examples of these types of responses can be found in Sections 4.1 and 4.2.2.

\subsubsection{Planning and Carrying out Investigations and Analyzing and Interpreting Data}

After the research questions were identified, the USF team developed a comparison matrix so that for each research question there were two BSFs that only differed by one independent variable (see Table 2).

Table 2. Experimental design for to ensure that two BSFs only differed by the one independent variable of the research question.

\begin{tabular}{|c|c|}
\hline HS Student Research Question & BSF Comparison \\
\hline \#1: How does the cleaning frequency of the BSF & Hydraid BSF \#1: Clean BSF twice per week. \\
\hline affect the quality of the filtered water? & Hydraid BSF \#2: Clean BSF when clogged. \\
\hline \#2a: How does the charging volume affect the & Hydraid BSF \#2: Charging volume 4 gallons. \\
\hline quality of the filtered water in the Hydraid design? & Hydraid BSF \#3: Charging volume 2 gallons. \\
\hline \#2b: How does the charging volume affect the & 2-Bucket design BSF \#1 Charging volume 4 gallons. \\
\hline quality of the filtered water in the 2- Bucket design? & 2-Bucket design BSF \#3 Charging volume 2 gallons. \\
\hline \#3: How does the type of BSF affect the quality of the & (note: all other independent \\
\hline filtered water? & variables the same for both BSFs) \\
\hline \#4: How does the addition of corn syrup affect the & 2-Bucket design BSF \#2: Corn syrup added to BSF \\
\hline quality of the filtered water? & 2-Bucket design BSF \#1: No corn syrup added to BSF \\
\hline $\begin{array}{l}\text { \#5: What are the best methods to operate the BSF to } \\
\text { produce the highest quality of water with the least } \\
\text { amount of maintenance? }\end{array}$ & All BSFs \\
\hline
\end{tabular}


Most of the planning for the research was performed with each whole class under the direction of the university team and Mr. Munro. Each section of the science course was responsible for the operation of one BSF and for collecting and analyzing the data from it. The HS students were taught to use the same analytical methods with the same instruments as the university students used for measuring turbidity, $\mathrm{pH}$, and flow rate. That the practices used by HS students were identical to those used for the university-based research added to the authenticity of the research to the students [38] and its characterization of meaningful engagement in scientific practices in the classroom [37].

In addition to turbidity, $\mathrm{pH}$, and flow rate, the HS students measured nitrate, nitrite, ammonia, and temperature of the influent and effluent water. The nitrate, nitrite, and ammonia were measured using commercially available test kits for aquaria. These tests were conducted because the water source was the freshwater aquaria that the students set up for their science class. The idea was that if these levels were reduced enough, the water could be put back into the tanks. For some of the BSFs it was and the water was reused. This added to the authenticity of the research because the water was from and for the aquaria they were maintaining, which made the investigation more meaningful to the students [38]. In addition, the introductory materials described how nitrate is a dissolved inorganic compound that is the most common groundwater contaminant worldwide and causes methemoglobinemia (blue baby syndrome). This may also have added to the meaningfulness of the nitrate measurement.

The HS students engaged in practices that were connected to both the universitybased research (developing low-cost methods to provide high quality drinking water) and their school science activity (the maintenance of the aquaria). As a result, they were engaged in practices that were meaningful to both the scientific and classroom communities, which places the meaningfulness of the BSF research project between the extremes in Berland et al.'s [37] continuum.

The data from the interviews of the HS students, their final reports, and our observations provide overwhelming evidence that the HS students carried out investigations using the methods noted above. For example, Dante told us the following:

Well, we put water from our fish tanks into the biosand filter, measured the flow rate, temperature, the nitrates and ammonium, on the other side of the biosand filter. And over time we measured how clean the water got, and the smell of the room and, you know, things were happening ...

Other examples include, "I also helped in testing these biosand filters, testing for ammonia, $\mathrm{pH}$, dissolved oxygen, temperature, etc. Um, you know, to determine whether the water's safe to drink or not" (Alejandro); and, "I participated in pretty much every aspect, like the building aspect, the designing aspect and the like weekly testing" (Daniela). Lucía described her work in the project in this manner, "I just tested out the difference between the tank, aquarium water, and the water in the biosand filter". The USF team observed the students engaged in taking samples and making measurements during our visits to the school. The report template that Mr. Munro provided to the HS students asked them to describe their research activities. While the descriptions tended to be rather terse, they all included aspects of how they carried out their investigations.

The HS students entered their data into a Google sheet that was accessible to all the students, Mr. Munro, and the USF team. At the end of the testing period, the USF team helped the HS students graph their data. The report template asked them to use their data and graphs to answer their research questions. While we observed the students engaged in these activities, they said little in the interviews about analyzing or interpreting their data. For example, one student shared, "Well, we found out that over time the water we put in the nitrates, we get lower, the floor rate slow. Like at the beginning, it was faster than right now, like the flow rate stays a little trickle" (Dante).

Similarly, in their reports, they presented the results of their analysis, but not the analysis itself. For example, Alejandro wrote the: 
We were testing nitrate and we wanted it to be low. Our results were good, and the level of nitrates was lower than [class] Period 4. We were also testing turbidity. We wanted turbidity to be low. Our results were worse than Period 4 because their biolayer was thicker, therefore the water had more time to filter.

Darius wrote the following:

Today I will compare and contrast how the charging volume affects the quality of the filtered water in the Hydraid design, 2 gallons vs. 4 gallon [charging volume]. And what are the best ways to operate the BSF to produce the highest quality water with the least amount of maintenance. I believe that our 2 gallon [charging volume] Hydraid filter is more efficient compared to the 4 gallon charge.

As we noted in Section 4.2.1, what we report here could be evidence of the students simply going through the data collection and analysis process in the same mechanical manner that they would in typical school science activities. However, as with the stage of asking of questions, the students' engagement in Planning and Carrying Out Investigations and Analyzing and Interpreting Data can be interpreted to have authenticity for the students. As Burgin [38] argued, the participation is more authentic if results are significant to others; if the project is meaningful to the students; and if the practices involved are likely to be used in professional science. In Section 4.2.1 we showed how the students observed the BSF project as significant to others as well as meaningful to themselves. We now provide evidence that the HS students observed what they were doing as similar to the practices used by scientists and engineers.

In our interviews we asked the HS students in what fashion this project was similar to or different from what you think scientists conduct in their daily work and in what fashion was it similar to or different from what they have performed in their regular science classes. Our analysis of the interviews indicated that they were aware of the major differences between this BSF project and their science experiences in schools. The differences noted by the students included: in their projects they worked in groups over a long time period (almost all of the spring semester); the results were not known ahead of time; they had the opportunity to use their creativity; they conducted more analysis of data to draw conclusions; and that the scientists (USF team) were in their school. For example, Daniela shared, "It [the project] was more organized and more structured, and we were very consistent with it". Alejandro told us the following:

This is [the project] a lot more inclusive and a lot more interactive than, um, a lot of many other things that I've ever done in science. Usually, I'm sitting in class, um, you know, staring at a Whiteboard, um, uh, looking at problems or, you know, just listening to lectures. But this is really something different. This is, um, you know, actual scientific research and working with the university. Um, it's very interactive... It really opens up a different view for science, um, that it wouldn't have opened up before. Um, generally actually experiencing, um, what some real research is like in, in a college-level, uh, is definitely different from your regular chemistry class or biology class that you, that you might take at a high school.

In his statement, he argued that this project differs from a regular science class because he played an active role as a researcher while cooperating with the USF team.

Similarly, Martina said the following, "Usually in schools you don't get to do projects from an engineering view, like testing wise". She went on to state how this was different from simply knowing the answers to exam questions. She acknowledged the importance of unknown results in the belief of her ability to conduct science and engineering and becoming a scientist through participating in this project.

Some students noted that they felt more like scientists than when doing regular school science activities because they were using practices similar to those used by scientists. For example, Alberto told us the following, "We had to keep experimenting with making sure that we had the correct amount of water, the correct amount of sand, rocks, and enough to make sure that whenever we did it, it actually worked correctly". Mila stated the following, 
"I gave ideas of the design, how we can build it. We were like testing to see if the water was good and like if it actually likes, um, help the fishes. And we were testing it for like weeks!" Darius summarized his participation in the following:

So we found different ways to create a filter that was efficient enough then we saw how it worked and how different from the water in the tank, how over time it collected ammonia and stuff and how the filter would actually clean that water and get rid of all that stuff that's not purified.

The HS students' awareness of the relationship between what they performed in the project and scientists' work was also reinforced by the presence of the USF team of researchers in the school. From the very beginning of the project, the USF team emphasized that the HS students would be engaged in research that was similar to the research they were conducting at the university. The HS students interacted on almost a weekly basis with the graduate students (Rice and Yang), whose thesis and dissertation work focused on the use of BSFs (co-authors of this paper and whose research is summarized in Section 3.2). Rice and Yang instructed the HS students in the methods of sampling and measuring the quality of the BSF influent and effluent. In addition, the HS students were aware that a modification of their two-bucket design was being used by the graduate students' research. In summary, the HS students' awareness of how their engagement in the project was similar to the practices of scientists; the graduate students who they came to know; and that the research was different from school science activities support that they had meaningful engagement in scientific practices in their classroom [37]. Mila expressed it the following:

I feel awesome. I'm like, wow, I've never experienced this before. So, when you guys came, I was like, I didn't know like universities can do that. It's like professors could gather together and say, okay, how can we help? Like these people who are suffering, like they can't afford this stuff. So, like I thought it was awesome. I'm glad that you guys came to us.

\subsubsection{Communicating Information}

The fourth science practice highlighted by Burgin in his framework is Communicating Information. Our original plan was for the HS students to make oral presentations of their results to an audience that included their peers, the USF team, their teacher and other teachers, and possibly others. We believe this would have added to the authenticity of the project [38] by having the students involved in the practice of scientific communication and as a method for acknowledging the significance of their work to others. It may also have made it more meaningful to them since they experienced the interest of others in their work. However, this did not occur because of the vagaries of the school calendar. As a result, the only formal communication of information was by the reports, which were read by Mr. Munro and the USF team. Unfortunately, the final reports were written in a manner that Berland et al. [37] would categorize as those that are meaningful to the classroom, i.e., school science. We discuss this further in Section 5 . The students were also asked to make oral and written presentations about their progress throughout the research process. This included presentations of their research questions using the whiteboards, their sketches and explanations of their designs for the BSF (see Figure 2), and oral updates of their data collection process. Although these types of communication are often part of school science, the authentic nature of the scientific activities [38] places them somewhat toward the middle of Berland et al.'s [37] continuum.

As it turned out, the students did engage in communications with those outside of the classroom and scientific communities. We learned through our interviews with the HS students that it was not uncommon for them to talk with their families about the project. Darius told us about speaking with his mother about the project:

I told my mom about it and she thought it was very interesting and told her about how it works in what we're actually doing with, with the biosand filter and what the ultimate 
goal is, bringing it to other places and making water available. I also told my sister about it as well.

Similarly, Luna described her talk with her father:

[I told my father] we had papers about biosand filters and I showed him the papers and then we looked up a video of like people building like filters and he was like this is this, this is that. And it was nice.

Martina had conversations with her friends and her mother:

I've talked to my friends ... [and] I've talked to my mom about this project. They really like it because they, they understand my, my, my, my perspective and my passion of helping other people and seeing other people struggle. So like they'll listen to me and they're like, whoa, that's our really nice, uh, project.

In another example, Carla shared her concern about the water they used in her home:

I have changed like different water that we drink. You know, I've done research on how ... what's better water to drink? ... There are some that are not really filtered all the way. So I've told my mom like, you know, no, we shouldn't get that water. We should get this.

In this manner, the HS students demonstrated that the hydrosocial knowledge they gained about water was shared with others.

\subsubsection{Summary}

In this section, we addressed our second sub-question by examining the methods by which the HS students engaged in science and engineering activities that correspond to some of the practices in the framework [19]. We have shown that for all except Communicating Information, the HS students experienced them authentically [38] and meaningfully [37]. In addition, they were able to explore water knowledge that was hydrosocial, local, and functional [3]. However, we are also interested in how their engagement in these activities related to their learning of conduct in science and engineering.

According to Feldman et al.'s $[52,53]$ model of learning to do research, when students participate in research groups, they progress on a continuum from novice researchers to proficient technicians to knowledge producers. This development occurs as the students gain methodological and intellectual proficiency. The HS students in this project began as entry level novice researchers. As we demonstrated above, during the project they engaged authentically and meaningfully in science and engineering activities [37,38]. In this manner, they learned how to ask questions and define problems and how to carry out their investigations and analyze their data. According to Feldman et al., [52] this suggests that the HS students were gaining methodological proficiency. Intellectual proficiency is associated with other science and engineering practices [19], including interpreting data; engaging in argument from evidence; evaluating and obtaining and communicating information; and the use of mathematical rather than physical models. Although the first three of these were built into the structure of the project, they did not fully occur because the implementation of the project took longer than expected and these activities bumped up against the end of the academic year. As a result, there was not enough time for the HS students to begin to develop intellectual proficiency. This is consistent with the experiences of novices in short term research experiences [52]. It is also possible that because the HS students were not immersed in a research group as university student apprentices would be, it impeded their development as researchers. The HS students' development along the research continuum may be best summed up by this quote from Lucía:

I feel it was like someway similar to what scientists would do, but I kind of feel like it's also a bit different because, well, you know, it's like kind of like taking baby steps. So to start off some something simple and then you know, move on to the next challenge. 


\subsection{Other Effects on the HS Students}

We used the opportunity to interview the HS students to explore other possible effects on them in their participation in the BSF project. We asked how it affected their interest in science and in STEM careers and how it affected their identities as scientists.

\subsubsection{Attitudes toward Science and STEM Careers}

We found evidence from our analysis of the HS students interviews that they had an increased interest in science and science-related careers including engineering, medicine, and public health. In this section we provide several exemplars that demonstrated this. First, Lucía shared how engagement in these activities changed her thoughts about science and increased her interest in a STEM career:

I'm more of a kind of artistic kind of person and I would like to improve on art rather than just science but [after the project] I mean a kind of mixture of wanting to be an artist and wanting to be a scientist. Cause you know, being a scientist means like you're helping people and give life to the community, you know, experimenting with a couple of things, but being an artist means you're expressing yourself; you're helping yourself.

In the same fashion, Alberto's statement reflected on the impact of these activities on his desire to become a scientist:

To be honest, I really haven't been thinking much of what I should do in the future ... I was always interested in science, but I never got further into it. But now, I think that it would be cool if I did [become a scientist] because then I'd be able to help more people

Other students told us about how their participation in the project enhanced their interest in STEM careers. For example, Mila told us how the project supported her passion to study public health:

I was really excited about it because it is part of like public health, and that is what I want to major in. So like if the water quality isn't good then you will get sick from bacteria or viruses. They would help like affect a lot of poor people in Africa, who can't afford like a filter and they get sick and they die. So it's really connected to public health!

In these excerpts it can be observed that the students related their increased interest to their interest in helping people. As we noted in the introduction to this paper, a challenge in educating young people about water issues is the nature of school science being unrelated to daily lives and having limited or no connection with real world problems. For most of the HS students we worked with, the lack of potable water was most likely not an issue in their daily lives (see Section 4.2.4 for exceptions to this); however, the challenge of providing people in other parts of the world with potable water resonated with them (see Section 4.2.1 for more evidence of this concern). This suggests that because the HS students knew that the BSF project was significant to others, it increased its authenticity [38] and meaningfulness [37] to each of them, which appears to have carried over to an increased interest in science and STEM careers.

\subsubsection{Perceptions of Themselves as Scientists}

In Section 4.2.2 we presented evidence that the HS students saw the BSF project as being different from school science. We also found evidence in our data that the HS students' engagement in the BSF project positively impacted their sense of scientific identity. In our observations and our informal conversations with the students, they appeared to take on a sense of not only performing science but also of seeing themselves as scientists. This was evident in their responses to our interview question about whether they were being a scientist when they were working on this project. Overall their answers reflected recognition of themselves and by others as scientists, which are two components of science identity according to Carlone and Johnson [79]. For example, Alberto told us how he saw his participation in the project engaged him to the point of feeling like a scientist: 
Yes, yes. I, actually, I did think of myself as a scientist during this. Um, usually I think of myself as a student when I'm in a science class, but, um, I think this project really engages us so much that we become, the scientists at this point.

Other students provided more details as to why they saw themselves as scientists. For example, Mila told us the following:

Yeah! I was like testing the water quality, and I was like using machines that, uh, scientists will use that I've like never like seen before. And I was actually like, um, like researching about like the water and like how would you like benefits and like, like looking for everything. Like something that I will not do like in it every day and something that scientist is doing. So, I think I was the kind of scientist in this project.

In the same manner, Jeb said:

If you took all these chemical measurements from the biosand filters and you did it consistently every week, and you cared about how they're operating, then I think to a degree you'd be more of a legitimate scientist than someone who is just asking for a grade. Right!

Luna also offered details of how her engagement in science practices was similar to those of scientists, "We were like scientists because we had to learn like $\mathrm{pH}$ levels ... what is in the water before we purify it. Like what damages the water and all those sorts of things". She continued by providing details of the procedures they performed and how it related to scientist's work. Similarly, Darius described what he was doing compared to the work of scientists' work in the following manner:

I believe so, yes ... I was able to analyze what I saw and then create observations and go off from that and make it better. Scientists they research to find better ways to do things. Thus, in this project, we researched to find better ways to get cleaner water to places where we could not get clean water or afford to bring ... They get hands-on, and they are actually in it. They understand what is happening, and they are finding better ways to fix that. So they're doing this thing and then they're finding better ways to do that.

These responses point to the importance of the students' knowledge and demonstrated that they were engaged in scientific practices similar to the methods scientists use. Darius added the importance of having a goal that is significant to others. Their engagement in these types of practices made the project more authentic [38] and meaningful to them, which gave them the sense that their participation was more similar to those of the community of scientists than that of school science [37]. Carla summed it up in this manner, "Yeah! We told each other we were like scientists ... you know, it feels good to be able to do this with the classroom and stuff. I haven't experienced it; I never thought I would be able to do it".

\subsection{Additional Results}

In this last part of the results section, we report on two additional results, which were not directly related to our research questions.

\subsubsection{Attitudes toward Conserving Water}

One unexpected finding was that engagement in the project led the students to be more conservative in their use of water at home. Although our study was not designed to raise the students' water usage awareness, it was contextualized through the focus on the shortage of potable water in arid countries. However, in the interviews the HS students told us methods that they were utilizing in reducing their water usage as a result of participating in the project. For example, Mila emphasized the importance of changing her daily habit of consuming water in following manner:

It actually made me think how we have the benefit of having water a lot of water and we wasted so much like in the shower we take so much time sometimes and we don't realize every minute that we waste water thousands of people could be drinking it, you know? 
So like it made me realize the way how we clean and how we use water, you made me appreciate water more.

In the same manner, Luna reported, "The biosand filter [project] made me more aware of how much water we waste and how America just wasted so much water. So much clean water that in other countries they don't have!"

There is the possibility that the authenticity and meaningfulness of the BSF project to the students led them to also question their own water use. We also wonder if this may have been due to the students in some manner empathizing with the young girl in Water Walk. This could be a question to consider in further research.

\subsubsection{Experiences in Their Home Countries or Those of Their Families}

Another unexpected finding was that some of the HS students had personal experiences with the lack of potable water because of (1) where they lived before immigrating to the US or (2) from visits to relatives who were still living in those countries. For example, Marco told us of his visit to his grandfather's farm in Cuba, where he helped to build a cistern to collect rainwater and Manny referred to his experience living in Cuba:

I remembered when I left there like, um, my mom had to get the water from the tap and boil it. But sometimes you only get the, like..um.. the country gives you the gas like once a month and if you spend the gas in boiling, what are you going to cook with? So you have to have a balance, and sometimes it doesn't work... And when you see like here in the United States, how much water is wasted and then having the opportunity to create a biosand filter that can help them is awesome.

Marcella shared her experiences when she lived in Colombia:

I feel the first time I heard of [this project], I was so happy because when I'm back in my country I see people in the north are struggling to get clean water and kids dying because they, they, they don't have access to clean water, which is like such a, it's just a basic need that we all have and it's so easy for us to get it. But for other people it's not that easy. So, I feel like this is like a really important achievement.

She continued:

Sometimes I take really long showers here. In Colombia I would take like really quick showers so the like the water bill won't come like so, so expensive. My mom is like, "remember what you use to do in Colombia?" It's just sometimes you like remember where you come from and then you go back to who you truly are.

This finding underscores the differences between the students' lives and those of the USF team because this should not have been unexpected given the home backgrounds of the students. As a result, what could have been a strong connection of the project to students' lives was overlooked by the USF team. The importance of connecting to students' home cultures has been explored extensively in the science education literature (see for example, the work of Barton and her colleagues [80-82]). It also suggests that when we consider the meaningfulness of engagement in scientific practices [37], it is important to consider the students' home communities, as well as the classroom and scientific communities.

\section{Discussion}

In this study we investigated the manner in which the participation in a research project with a focus on providing potable water in developing countries affected HS students. We found that the focus provided authenticity and meaningfulness to the students $[37,38]$. While it was clear from our interviews that they recognized the significance of their work for those who do not have ready sources of potable water, there is also the possibility that it was more meaningful to them on Burgin's framework as a result of what could be called an altruistic stance toward their research on the BSFs. Almost all the students we interviewed and almost all the final reports demonstrated the good feelings that they had about conducting this work that could be beneficial to people in need 
around the world. That is, the project may have been more meaningful to the HS students because they came to empathize or care for others. This affective aspect of authenticity and meaningfulness does show up in the literature. For example, both Burgin [38] and Kapon et al. [83] refer to Buxton's concept of youth-centered authenticity in which, "authenticity begins with the premise that learning is authentic when it takes as its starting point the interests, perspectives, desires, and needs of the students" [61]. Kapon et al. also relates authenticity to the personal relevance of the activities to the students, which includes their "sense of benefit, value, and meaningfulness, as well as agency and users and generators of what is learned" [83]. However, while these perspectives focus on either how the students see the activities as being useful or meaningful to themselves or to others, they do not explore the influence that the students' empathy or caring for others may have on how authentic or meaningful the activities are to the students themselves. We suggest that as further research is performed on students' participation in research activities, it may be important to consider factors such as their feelings of empathy or caring for others.

In our second sub-question, we asked about the relationship between the activities' authenticity and meaningfulness to the HS students and their learning of science and engineering practices. As we noted above, these activities allowed the HS students to explore the hydrosocial, local, and functional knowledge [3] of water supply issues and methods to address them using POU water treatment technology. This was possible because of the collaboration of the university-based research group with Mr. Munro and his students. The university-based research added to all of Burgin's dimensions of authenticity [38] and placed the activities in the region of meaningful engagement in scientific practices in classrooms of Berland et al.'s continuum [37]. As a result, the HS students found the experience to be very different from their regular science instruction, felt special and privileged to have the USF team in their school working with them, and were deeply drawn to the issue of lack of potable water in much of the world.

We also found that the authenticity and meaningfulness of the activities led the students to become more interested in science and STEM careers, and helped them to take on the identity as scientists. As our data indicates, these changes in attitudes had a strong connection to the real-world requirement for developing POU water treatment and the students' knowledge that they were contributing to finding a solution.

It appears that the authenticity and meaningfulness of the project to the HS students are related to our two unexpected findings. One was that even though there was no explicit instruction about the need to conserve water, the students determined that it was important for them to do so and gave us specific examples of the methods they were going use to realize water conservation. The other was that because many of the HS students were either new to the US or traveled to their family's home countries, they had personal experience with issues related to the scarcity of potable water. This type of knowledge is often referred to as "funds of knowledge". The term funds of knowledge refers to "historically accumulated and culturally developed bodies of knowledge and skills essential for household or individual functioning and well-being" [84]. It has been demonstrated that teaching that draws upon students' funds of knowledge can result in increased student involvement in lessons and improved learning $[82,85,86]$. In retrospect, we believe that our project could have made good use of the HS students' funds of knowledge related to water scarcity issues.

This project could not have happened without the help of Mr. Munro. He opened his classroom to us and encouraged his students to be active participants. Because the source of the water for the BSFs were the aquaria used for the science lessons, he had already taught the students about the nitrogen cycle and the need to keep nitrate, nitrite, and ammonia under control. He had also taught them how to perform the tests for these contaminants, which we adapted for the BSF research. In looking back at the project, we realize that while Mr. Munro was welcoming to us, we did not include him in our work as much as we ought to have. Our focus on the HS students blinded us to the need to welcome Mr. Munro into 
our research group so that he could share ownership of the project with us. We believe that this resulted in Mr. Munro stepping back when we worked with the students.

One aspect of Mr. Munro's stepping back was that he participated on the sidelines in the research activities in his classes. This was partly due to our not making sure that he saw himself as part of our research group. As a result, when he did provide help with the project, it was more similar to "school science" rather than authentic research. A case in point was the students' research reports. Mr. Munro developed the template for the reports and ran the class sessions when the students prepared them. Although we found the reports useful for uncovering the HS students' knowledge, skills, and beliefs about engaging in water research, it appears that they treated the template as if it was a worksheet. In the US, students have been enculturated to respond to worksheets by basically filling in the spaces between the questions and when every space has text in it, they have completed the worksheet [87]. This has been described as a "done is good" mindset. Not making sure Mr. Munro felt that he was a full participant in our research group was a serious short-coming in our design, which we plan to change in future iterations of the project or similar ones. Clearly, this is an important lesson for all future projects in which university research teams partner with teachers and their students to promote authentic school-based scientific research.

Another important caveat about this project and one that may have been related to Mr. Munro not feeling or being a part of the group is that it was very time-intensive for the USF team. In addition to the time elapsed in performing the educational research, there was the time spent in developing the curriculum material. Furthermore, the graduate students and professors spent a considerable amount of time in the school to teach the students about water issues, BSFs, and research methods. The USF team also taught the students how to build and operate the BSFs and some of the measurement methods. Because the project included all of Mr. Munro's six daily classes, the USF team needed to be at the school from the opening bell until the end of the day. Clearly this is not a sustainable model. One method to render it more sustainable is to work with teachers to improve their abilities in engaging in the practices of science and engineering so that they can serve as research team leaders at the school sites. For the 2019-2020 academic year, we modified the model of interaction with the schools so that the USF team worked directly with teachers from three high schools and one middle school to support the implementation of the project either as an afterschool activity or as part of the regular classes. The teachers would then teach the students much of the material about BSFs and research methods and engage in the authentic activities along with them. Our intent was to study whether this model would work and what factors affect its success. However, the implementation of this model was truncated by the shift to remote emergency teaching because of the COVID-19 pandemic. The USF team looks forward to continuing studying this model when schools re-open.

Author Contributions: Conceptualization, A.F., S.J.E. and K.G.; data curation, J.A., M.H., M.R. and X.Y.; formal analysis, J.A., M.H., M.R., A.F., S.J.E. and K.G.; funding acquisition, A.F., S.J.E. and K.G.; investigation, J.A., M.H., M.R., X.Y., J.K., A.F., S.J.E. and K.G.; methodology, J.A., M.R., X.Y., A.F., S.J.E. and K.G.; project administration, A.F., S.J.E. and K.G.; resources, A.F., S.J.E. and K.G.; supervision, A.F., S.J.E. and K.G.; visualization, J.A., J.K., A.F., S.J.E. and K.G.; writing-original draft, J.A., M.H., M.R., A.F., S.J.E. and K.G.; writing-review and editing, J.A., M.H., A.F., S.J.E. and K.G. All authors have read and agreed to the published version of the manuscript.

Funding: This research was funded by the JOY MCCANN FOUNDATION.

Institutional Review Board Statement: The study was conducted according to the guidelines of the Declaration of Helsinki, and approved by the Institutional Review Board of the University of South Florida (Pro00038914, 4/11/2019.

Informed Consent Statement: Informed consent was obtained from all subjects involved in the study.

Data Availability Statement: The data presented in this study are available on request from the corresponding author. The data are not publicly available due to anonymity promised to subjects as part of the consent process. 
Acknowledgments: We would like to thank Munro and his students, as well as the school district for their participation in the project. We would also like to thank Stephanie Arthur for her help with interviewing the HS students and Kammie Kisling for her assistance in operating and monitoring the university BSFs.

Conflicts of Interest: The authors declare no conflict of interest.

\section{References}

1. Sadler, T.D.; Nguyen, H.; Lankford, D. Water systems understandings: A framework for designing instruction and considering what learners know about water. Wiley Interdiscip. Rev. Water 2017, 4, e1178. [CrossRef]

2. Gunckel, K.L.; Covitt, B.A.; Salinas, I.; Anderson, C.W. A learning progression for water in socio-ecological systems. J. Res. Sci. Teach. 2012, 49, 843-868. [CrossRef]

3. McCarroll, M.; Hamann, H. What We Know about Water: A Water Literacy Review. Water 2020, 12, 2803. [CrossRef]

4. De Vos, W.; Bulte, A.; Pilot, A. Chemistry curricula for general education: Analysis and elements of a design. In Chemical Education: Towards Research-Based Practice; Gilbert, J.K., De Jong, O., Justi, R., Treagust, D.F., Van Driel, J.H., Eds.; Springer: Dordrecht, The Netherlands, 2002; pp. 101-124. [CrossRef]

5. Bulte, A.M.W.; Westbroek, H.B.; de Jong, O.; Pilot, A. A Research Approach to Designing Chemistry Education using Authentic Practices as Contexts. Int. J. Sci. Educ. 2006, 28, 1063-1086. [CrossRef]

6. Hellgren, J.M.; Lindberg, S. Motivating students with authentic science experiences: Changes in motivation for school science. Res. Sci. Technol. Educ. 2017, 35, 409-426. [CrossRef]

7. Osborne, J.; Collins, S. Pupils' views of the role and value of the science curriculum: A focus-group study. Int. J. Sci. Educ. 2001, 23, 441-467. [CrossRef]

8. Lyons, T. Different countries, same science classes: Students' experiences of school science in their own words. Int. J. Sci. Educ. 2006, 28, 591-613. [CrossRef]

9. Amahmid, O.; El Guamri, Y.; Yazidi, M.; Razoki, B.; Rassou, K.K.; Rakibi, Y.; Knini, G.; El Ouardi, T. Water Education in School Curricula: Impact on Children Knowledge, Attitudes and Behaviours towards Water Use. Int. Res. Geogr. Environ. Educ. 2019, 28, 178-193. [CrossRef]

10. Condon, M.; Wichowsky, A. Developing Citizen-Scientists: Effects of an Inquiry-Based Science Curriculum on STEM and Civic Engagement. Elem. Sch. J. 2018, 119, 196-222. [CrossRef]

11. Lally, D.; Forbes, C.T. Sociohydrologic Systems Thinking: An Analysis of Undergraduate Students' Operationalization and Modeling of Coupled Human-Water Systems. Water 2020, 12, 1040. [CrossRef]

12. Martínez-Borreguero, G.; Maestre-Jiménez, J.; Mateos-Núñez, M.; Naranjo-Correa, F.L. Water from the Perspective of Education for Sustainable Development: An Exploratory Study in the Spanish Secondary Education Curriculum. Water 2020, $12,1877$. [CrossRef]

13. Middlestadt, S.; Grieser, M.; Hernandez, O.; Tubaishat, K.; Sanchack, J.; Southwell, B.; Schwartz, R. Turning Minds On and Faucets Off: Water Conservation Education in Jordanian Schools. J. Environ. Educ. 2001, 32, 37-45. [CrossRef]

14. Zelenika, I.; Moreau, T.; Lane, O.; Zhao, J. Sustainability Education in a Botanical Garden Promotes Environmental Knowledge, Attitudes and Willingness to Act. Environ. Educ. Res. 2018, 24, 1581-1596. [CrossRef]

15. Zhan, Y.; He, R.; So, W.W.M. Developing Elementary School Children's Water Conversation Action Competence: A Case Study in China. Int. J. Early Years Educ. 2019, 27, 287-305. [CrossRef]

16. Lee, H.; Songer, N.B. Making authentic science accessible to students. Int. J. Sci. Educ. 2003, 25, 923-948. [CrossRef]

17. McComas, W.F. Nature of science in the science curriculum and in teacher education programs in the United States. In International Handbook of Research in History, Philosophy and Science Teaching; Matthews, M.R., Ed.; Springer: New York, NY, USA, 2014; pp. 1993-2023. [CrossRef]

18. Crawford, B.A. Moving the Essence of Inquiry into the Classroom: Engaging Teachers and Students in Authentic Science. In Issues and Challenges in Science Education Research: Moving Forward; Tan, K.C.D., Kim, M., Eds.; Springer: New York, NY, USA, 2012; pp. 25-42. [CrossRef]

19. National Research Council. A Framework for K-12 Science Education: Practices, Crosscutting Concepts, and Core Ideas; National Academies Press: Washington, DC, USA, 2012.

20. Laursen, S.; Hunter, A.-B.; Seymour, E.; Thiry, H.; Melton, G. Undergraduate Research in the Sciences: Engaging Students in Real Science; John Wiley \& Sons, Inc.: Hoboken, NJ, USA, 2010.

21. Sadler, T.D.; Burgin, S.R.; McKinney, L.; Ponjuan, L. Learning science through research apprenticeships: A critical review of the literature. J. Res. Sci. Teach. 2009, 47, 235-256. [CrossRef]

22. Bell, R.L.; Blair, L.M.; Crawford, B.A.; Lederman, N.G. Just Do It? Impact of a Science Apprenticeship Program on High School Students' Understandings of the Nature of Science and Scientific Inquiry. J. Res. Sci. Teach. 2003, 40, 487-509. [CrossRef]

23. Tsybulsky, D.; Dodick, J.; Camhi, J. High-school students in university research labs? Implementing an outreach model based on the 'science as inquiry'approach. J. Biol. Educ. 2018, 52, 415-428.

24. Aydeniz, M.; Baksa, K.; Skinner, J. Understanding the impact of an apprenticeship-based scientific research program on high school students' understanding of scientific inquiry. J. Sci. Educ. Technol. 2011, 20, 403-421. [CrossRef] 
25. Ballard, H.L.; Dixon, C.G.; Harris, E.M. Youth-focused citizen science: Examining the role of environmental science learning and agency for conservation. Biol. Conserv. 2017, 208, 65-75. [CrossRef]

26. Pitt, A.N.; Schultz, C.A.; Vaske, J.J. Engaging youth in public lands monitoring: Opportunities for enhancing ecological literacy and environmental stewardship. Environ. Educ. Res. 2019, 25, 1386-1399. [CrossRef]

27. Burgin, S.R.; McConnell, W.J.; Flowers, A.M., III. 'I Actually Contributed to Their Research': The influence of an abbreviated summer apprenticeship program in science and engineering for diverse high-school learners. Int. J. Sci. Educ. 2015, 37, 411-445. [CrossRef]

28. Burgin, S.R.; Sadler, T.D.; Koroly, M. High School Student Participation in Scientific Research Apprenticeships: Variation in and Relationships among Student Experiences and Outcomes. Res. Sci. Educ. 2012, 42, 439-467. [CrossRef]

29. Perin, S.M.; Carsten Conner, L.D.; Oxtoby, L.E. How various material resources facilitate science identity work for girls in a research apprenticeship program. J. Geosci. Educ. 2020, 68, 254-264. [CrossRef]

30. Sternheim, M.; Feldman, A. STEMRAYS: After-School STEM Research Clubs. In Exemplary STEM Programs: Designs for Success; Yager, R.E., Brunkhorst, H., Eds.; NSTA Press: Arlington, VA, USA, 2014; pp. 61-76.

31. Chapman, A.; Feldman, A. Cultivation of science identity through authentic science in an urban high school classroom. Cult. Stud. Sci. Educ. 2017, 12, 469-491. [CrossRef]

32. Long, B.J. An Examination of Whether Engaging in Authentic Science Has an Impact on High School Students' Agency to Achieve Ecojustice in Their Local Community. Ph.D. Thesis, The University of Tennessee, Knoxville, TN, USA, 2020.

33. Zimmerman, H.T.; Weible, J.L. Learning in and about rural places: Connections and tensions between students' everyday experiences and environmental quality issues in their community. Cult. Stud. Sci. Educ. 2017, 12, 7-31. [CrossRef]

34. Brown, J.S.; Collins, A.; Duguid, P. Situated cognition and the culture of learning. Educ. Res. 1989, 18, 32-42. [CrossRef]

35. Braund, M.; Reiss, M. Towards a more authentic science curriculum: The contribution of out-of-school learning. Int. J. Sci. Educ. 2006, 28, 1373-1388. [CrossRef]

36. Chinn, C.A.; Malhotra, B.A. Epistemologically authentic inquiry in schools: A theoretical framework for evaluating inquiry tasks. Sci. Educ. 2002, 86, 175-218. [CrossRef]

37. Berland, L.K.; Schwarz, C.V.; Krist, C.; Kenyon, L.; Lo, A.S.; Reiser, B.J. Epistemologies in practice: Making scientific practices meaningful for students. J. Res. Sci. Teach. 2016, 53, 1082-1112. [CrossRef]

38. Burgin, S.R. A three-dimensional conceptualization of authentic inquiry-based practices: A reflective tool for science educators. Int. J. Sci. Educ. 2020, 42, 1465-1484. [CrossRef]

39. Kollmuss, A.; Agyeman, J. Mind the gap: Why do people act environmentally and what are the barriers to pro-environmental behavior? Environ. Educ. Res. 2002, 8, 239-260. [CrossRef]

40. Coban, G.U.; Akpinar, E.; Kucukcankurtaran, E.; Yildiz, E.; Ergin, O. Elementary School Students' Water Awareness. Int. Res. Geogr. Environ. Educ. 2011, 20, 65-83. [CrossRef]

41. Havu-Nuutinen, S.; Kärkkäinen, S.; Keinonen, T. Changes in primary school pupils' conceptions of water in the context of Science, Technology, and Society (STS) instruction. Int. Res. Geogr. Environ. Educ. 2018, 27, 118-134. [CrossRef]

42. Al-Rabaani, A.H.; Al-Aamri, I.H. The Effect of Using Cartoons on Developing Omani Grade 4 Students' Awareness of Water Issues and Their Attitudes towards Using Them in Teaching Social Studies. J. Soc. Stud. Educ. Res. 2017, 8, 35-46.

43. Davis, N.R.; Schaeffer, J. Troubling Troubled Waters in Elementary Science Education: Politics, Ethics \& Black Children's Conceptions of Water [Justice] in the Era of Flint. Cogn. Instr. 2019, 37, 367-389.

44. Miller, M.G.; Davis, J.M.; Boyd, W.; Danby, S. Learning about and taking action for the environment: Child and teacher experiences in a preschool water education program. Child. Youth Environ. 2014, 24, 43-57. [CrossRef]

45. Seehamat, L.; Sanrattana, U.; Tungkasamit, A. The Developing on Awareness of Water Resources Management of Grade 6 Students in Namphong Sub-Basin. Int. Educ. Stud. 2016, 9, 156-165. [CrossRef]

46. Thompson, R.; Coe, A.; Klaver, I.; Dickson, K. Design and Implementation of a Research-Informed Water Conservation Education Program. Appl. Environ. Educ. Commun. 2011, 10, 91-104. [CrossRef]

47. Medrano, J.; Jaffe, J.; Lombardi, D.; Holzer, M.A.; Roemmele, C. Students' Scientific Evaluations of Water Resources. Water 2020, 12, 2048. [CrossRef]

48. Stevenson, R.B. Schooling and environmental education: Contradictions in purpose and practice. Environ. Educ. Res. 2007, 13, 139-153. [CrossRef]

49. Halsey Randall, M.M. Developing NGSS Scientific Practices through Inquiry in an Outdoor Learning Environment. Ph.D. Thesis, Oregon State University, Corvallis, OR, USA, 2016.

50. Smith, G.A. Place-based education: Breaking through the constraining regularities of public school. Environ. Educ. Res. 2007, 13, 189-207. [CrossRef]

51. Gruenwald, D.A.; Smith, G.A. Place-Based Education in the Global Age; Lawrence Erlbaum Associates: New York, NY, USA, 2007.

52. Feldman, A.; Divoll, K.; Rogan-Klyve, A. Becoming Researchers: The participation of undergraduate and graduate students in scientific research groups. Sci. Educ. 2013, 97, 218-243. [CrossRef]

53. Feldman, A.; Divoll, K.; Rogan-Klyve, A. Research education of new scientists: Implications for science teacher education. J. Res. Sci. Teach. 2009, 46, 442-459. [CrossRef]

54. Bloom, J.E.; Yuretich, R.F.; Gál, N.E. Environmental Consequences of Acid Mine Drainage from Davis Pyrite Mine, Rowe, Massachusetts. Northeast. Geol. Environ. Sci. 2007, 29, 108-121. 
55. Yuretich, R.; Ergas, S.J.; Ahlfeld, D.; Nuesslein, K.; Feldman, A. Environmental consequences of acidic drainage from Davis Pyrite Mine, Rowe, Massachusetts. In Proceedings of the 32nd International Geological Congress (32IGC), Florence, Italy, 20-28 August 2004.

56. Bucher, R.; Stelling, J.G. Becoming Professional; Sage Publications: Beverly Hills, CA, USA, 1977; Volume 46.

57. Osbeck, L.M.; Nersessian, N.J.; Malone, K.R.; Newstetter, W.C. Science as Psychology: Sense-Making and Identity in Science Practice; Cambridge University Press: New York, NY, USA, 2011.

58. Stucky, A.P. Empirical Grounding of the Nature of Scientific Inquiry: A Study of Developing Researchers. Ph.D. Thesis, University of Kansas, Lawrence, KS, USA, 2005.

59. Lave, J.; Wenger, E. Situated Learning: Legitimate Peripheral Participation; Cambridge University Press: Cambridge, UK, 1991. [CrossRef]

60. Eagan, M.K.; Hurtado, S.; Chang, M.J.; Garcia, G.A.; Herrera, F.A.; Garibay, J.C. Making a difference in science education: The impact of undergraduate research programs. Am. Educ. Res. J. 2013, 50, 683-713. [CrossRef]

61. Buxton, C.A. Creating contextually authentic science in a "low-performing" urban elementary school. J. Res. Sci. Teach. 2006, 43, 695-721. [CrossRef]

62. Rivera Maulucci, M.S.; Brown, B.A.; Grey, S.T.; Sullivan, S. Urban middle school students' reflections on authentic science inquiry. J. Res. Sci. Teach. 2014, 51, 1119-1149. [CrossRef]

63. WHO. Drinking-Water: Fact Sheet. Available online: https://www.who.int/news-room/fact-sheets/detail/drinking-water (accessed on 1 September 2019).

64. UNICEF. Progress on Household Drinking Water, Sanitation and Hygiene 2000-2017; United Nations Children's Fund (UNICEF) and World Health Organization: New York, NY, USA, 2019.

65. Alsultan, J.; Rice, M.; Feldman, A.; Nkrumah, T.; Ergas, S.; Ghebremichael, K. Biosand Filters for Water Purification. Sci. Teach. 2021, 88, 41-46.

66. Pooi, C.K.; Ng, H.Y. Review of low-cost point-of-use water treatment systems for developing communities. NPJ Clean Water 2018, 1, 1-8. [CrossRef]

67. CAWST. What Is a Biosand Filter? Available online: https://www.cawst.org/services/expertise/biosand-filter/moreinformation (accessed on 23 October 2019).

68. Lynn, T.J.; Wanjugi, P.; Harwood, V.J.; Ergas, S.J. Dynamic performance of biosand filters. J. Am. Water Works Assoc. 2013, 105, E587-E595. [CrossRef]

69. Murphy, H.M.; McBean, E.A.; Farahbakhsh, K. A critical evaluation of two point-of-use water treatment technologies: Can they provide water that meets WHO drinking water guidelines? J. Water Health 2010, 8, 611-630. [CrossRef]

70. Feldman, A.; Pirog, K. Authentic science research in elementary after-school science clubs. J. Sci. Educ. Technol. 2011, 20, 494-507. [CrossRef]

71. Feldman, A.; Chapman, A.; Vernaza-Hernández, V.; Özalp, D.; Alshehri, F. Inquiry-Based Science Education as Multiple Outcome Interdisciplinary Research and Learning (MOIRL). Sci. Educ. Int. 2012, 23, 328-337.

72. Rice, M. Enhanced Fluoride Removal in Biosand Filters Using Aluminum Oxide Coated Media and Modified Filter Design. Master's Thesis, University of South Florida, Tampa, FL, USA, 2020.

73. Fetterman, D.M. Ethnography: Step-by-Step, 4th ed.; SAGE Publications: Thousand Oaks, CA, USA, 2019.

74. Patton, M.Q. Qualitative Research and Evaluation Methods, 4th ed.; SAGE Publications, Inc.: Thousand Oaks, CA, USA, 2015. [CrossRef]

75. Corbin, J.; Strauss, A.C. Basics of Qualitative Research: Techniques and Procedures for Developing Grounded Theory, 4th ed.; Sage Publications: Thousand Oaks, CA, USA, 2015.

76. Lichtman, M. Qualitative Research in Education: A User's Guide, 3rd ed.; Sage Publications: Thousand Oaks, CA, USA, 2013.

77. WaterAid. Water Walk; YouTube: London, UK, 2014; Available online: https://youtu.be/4V-KoJGGJ4s (accessed on 19 August 2019).

78. Barb, K.; Everett, J.W. Clean Water for La Ceiba El Salvador-Household Biosand Filters. Int. J. Serv. Learn. Eng. Humanit. Eng. Soc. Entrep. 2014, 9, 40-63. [CrossRef]

79. Carlone, H.B.; Johnson, A. Understanding the science experiences of successful women of color: Science identity as an analytic lens. J. Res. Sci. Teach. 2007, 44, 1187-1218. [CrossRef]

80. Barton, A.C. Science Learning in Urban Settings. In Handbook of Research on Science Education; Abell, S.K., Lederman, N.G., Eds.; Lawrence Erlbaum Associates: Mahwah, NJ, USA, 2007; pp. 319-344.

81. Tan, E.; Barton, A.C.; Turner, E.; Gutiérrez, M.V. Empowering Science and Mathematics Education in Urban Schools; University of Chicago Press: Chicago, IL, USA, 2012.

82. Basu, S.J.; Barton, A.C. Developing a sustained interest in science among urban minority youth. J. Res. Sci. Teach. 2007, 44, 466-489. [CrossRef]

83. Kapon, S.; Laherto, A.; Levrini, O. Disciplinary authenticity and personal relevance in school science. Sci. Educ. 2018, 102, 1077-1106. [CrossRef]

84. Moll, L.C.; Amanti, C.; Neff, D.; Gonzalez, N. Funds of knowledge for teaching: Using a qualitative approach to connect homes and classrooms. Theory Pract. 1992, 31, 132-141. [CrossRef] 
85. Barton, A.C.; Tan, E. Funds of knowledge and discourses and hybrid space. J. Res. Sci. Teach. Off. J. Natl. Assoc. Res. Sci. Teach. 2009, 46, 50-73. [CrossRef]

86. Upadhyay, B. Teaching science for empowerment in an urban classroom: Using Hmong students' funds of knowledge. Equity Excell. Educ. 2009, 42, 217-232. [CrossRef]

87. Doyle, W. Academic work. Rev. Educ. Res. 1983, 53, 159-199. [CrossRef] 